\title{
ASPEK PENGETAHUAN DALAM TUTURAN BERTANYA GURU BAHASA INDONESIA DALAM PROSES PEMBELAJARAN
}

\author{
Guntur Sakti Dewangga \\ SMA Negeri 1 Mojotengen, Wonosobo, Jateng \\ email: guntursaktidewangga@gmail.com
}

\begin{abstract}
ABSTRAK
Penelitian ini mengkaji masalah tentang aspek pengetahuan dalam tuturan bertanya guru bahasa Indonesia. Objek dalam penelitian ini adalah tuturan bertanya guru bahasa Indonesia dalam proses pembelajaran.Data dalam penelitian ini dianalisis dengan teknik analisis kualitatif. Dari hasil analisis ditemukan empat tingkatan/level aspek pengetahuan dalam tuturan bertanya guru bahasa Indonesia, yaitu level I-Low Order Convergent, level II-High Order Convergent, level III-Low Order Divergent, dan level IV-High Order Divergent. Hasil temuan tersebut menunjukkan bahwa dalam kegiatan pembelajaran banyak ditemukan tuturan tanya guru dengan tingkat/level I. Hal ini berarti tuturan tanya guru dalam proses pembelajaran banyak menggunakan tuturan dengan aspek pengetahuan yang sederhana atau rendah. Hasil analisis menunjukkan ada tiga temuan terkait konten/isi dalam tuturan bertanya guru bahasa Indonesia, yaitu pertanyaan konseptual, pertanyaan empiris, dan pertanyaan nilai. Dari ketiga isi tuturan bertanya tersebut, yang paling banyak muncul adalah tuturan bertanya konseptual. Hal tersebut dikarenakan dalam pembelajaran guru banyak mengajukan pertanyaan terkait konsep materi tertentu.
\end{abstract}

Kata Kunci: aspek pengetahuan, konten, tuturan, tanya, pembelajaran

\section{KNOWLEDGE ASPECT OF INTERROGATIVE SPEECH OF INDONESIAN LANGUAGE TEACHERS IN TEACHING PROCESSES}

\begin{abstract}
This study aims knowledge aspect of interrogative speech of Indonesian language teachers. The objectwas interrogative speechs of Indonesian language teachers. The data was analyzed by content analysis techniques. Based on data analysis reaveals four levels of knowledge aspect in interrogative speech of Indonesian language teachers: level I-Low Order Convergent, level II-High Order Convergent, level III-Low Order Divergent, and level IV-High Order Divergent. The result reaveals that interrogative speech of Indonesian language teachers level I was most frequently used. It's mean, the teachers used many interrogative speech level I or low knowledge aspect in teaching processes. There are three contents of the interrogative speech act of Indonesian teachers in teaching processes: conceptual question, empirical question, and value question. Of the three contents of the question, the most frequently used is conceptual question, because in teaching the teachers ask more about the concept of a particular material.
\end{abstract}

Keywords: knowledge aspect, content, speech, interrogative, teaching

\section{PENDAHULUAN}

Pembelajaran merupakan suatu proses yang dilakukan secara sadar pada setiap individu atau kelompok yang merubah sikap dari tidak tahu menjadi tahu, dari tidak bisa menjadi bisa. Proses belajar mengajar adalah satu kegiatan yang di dalamnya terjadi proses siswa belajar dan guru mengajar di mana terjadi interaksi edu- katif antara guru dan siswa, sehingga terdapat perubahan pemahaman dalam diri siswa baik perubahan pada tingkat pengetahuan, pemahaman, dan keterampilan sikap. Setiap pembelajaran yang berlangsung di kelas tentunya diharapkan dapat berjalan interaktif dan komunikatif. Untuk mewujudkan suasana pembelajaran yang interaktif guru dapat menggunakan beberapa strategi 
yang dapat membangun interaksi dengan siswa. Salah satu cara untuk membangun interaksi dengan siswa, yaitu dengan membangun komunikasi dua arah dalam proses pembelajaran. Jika komunikasi yang berlangsung dalam kelas hanya komunikasi satu arah dimungkinkan siswa merasa bosan, karena tidak ada kesempatan untuk siswa bertanya.

Untuk menghindari kegagalan dalam berkomunikasi di kelas, seorang guru harus memiliki kompetensi berbahasa yang memadai dan keterampilannya dalam mengelola kelas. Keterampilan berbahasa meliputi kemampuan guru menggunakan pilihan kata dan kalimat secara tepat. Penggunaan bahasa secara tepat dan sesuai konteks dapat membangun suasana belajar yang interaktif. Tindak tutur yang digunakan guru sesuai dengan keadaan siswa sebagai mitra tuturnya. Pembelajaran yang interaktif dapat diciptakan oleh guru dengan tindak tutur bertanya (mengajukan pertanyaan-pertanyaan kepada siswa). Apabila guru dapat menggunakan dan memanfaatkan tindak tutur bertanya dengan baik sesuai dengan fungsinya, suasana pembelajaran dapat berjalan dengan baik, interaktif dan lebih hidup. Tindak bertanya guru di dalam kelas memiliki peranan yang penting dalam proses pembelajaran. Strategi bertanya guru dapat membantu siswa untuk memahami berbagai materi yang dipelajari baik berasal dari buku teks maupun sumber belajar yang lain (Syamsi, 2015).

Dalam pembelajaran bahasa Indonesia di kelas, tindak tutur bertanya guru mempunyai fungsi yang luas. Tuturan bertanya guru yang paling dasar memiliki fungsi untuk menguji pemahaman siswa tentang apa yang telah dipelajari pada waktu itu. Kindsvatter, Willen, \& Ishler (1996) membagi menjadi empat level pertanyaan yang digunakan untuk mencapai tujuan instruksional, yaitu level I (Low-Order Convergent), level II (High-Order Convergent), level III (Low-Order Divergent), dan level IV (High-Order Divergent). Keempat tingkatan itu berangkat dari pengklasifikasian tingkatan berpikir Bloom yang kemudian disederhanakan menjadi empat tingkatan (level I - IV) oleh Kindsvatter, Willen, \& Ishler. Tingkatan terse- but digolongkan dari tingkat sederhana sampai tingkat yang kompleks. Berikut keempat level pertanyaan dari beberapa tujuan instruksional yang ingin dicapai (Kindsvatter, Willen, \& Ishler, 1996: 197-198).

Level I - Low Order Convergent; pertanyaan memerlukan siswa untuk berpikir produktif. Tujuannya untuk siswa mengingat atau mengenali informasi. Level ini menekankan pada penguasaan memori dan observasi atau pengamatan siswa. Level I ini sesuai dengan taksonomi Bloom level "pengetahuan". Pada level ini siswa diharapkan mampu mendefinisikan, mengenali, mengidentifikasi, menjawab benar atau tidak, dan mengingat kembali. Contoh pertanyaan dalam level ini adalah sebagai berikut.

\section{[1]"Apa fungsi dari teks anekdot?" \\ Level II - High Order Convergent;} pertanyaan level ini bermaksud supaya siswa berpikir kembali dan mendemonstrasikan pemahaman mengenai informasi atau topik. Siswa juga belajar mengaplikasikan informasi. Level II ini sesuai dengan tingkatan "komprehensi" dan "aplikasi" pada taksonomi Bloom. Pada level ini dapat ditandai dengan siswa mampu menggambarkan, membandingkan, meringkas, menghubungkan, menginterpretasi, memberikan contoh. Contoh pertanyaannya sebagi berikut.

[2]"Gagasan yang sesuai dengan teks tersebut ialah?"

Level III - Low Order Divergent; pada level ini siswa dituntut untuk berpikir kritis tentang informasi atau topik masalah. Tujuan guru pada pertanyaan ini adalah siswa menganalisis informasi, menemukan alasan atau penyebab, menarik kesimpulan atau menggeneralisasi, atau menemukan bukti untuk mendukung opininya tentang suatu topik. Level ini sesuai dengan taksonomi Blomm pada tingkatan "analisis". Pada level ini dapat ditandai dengan siswa mampu mengidentifikasi motif, alasan atau penyebab, menarik kesimpulan, memberikan bukti untuk mendukung ide, menganalisis informasi. Contoh pertanyaan dalam level ini adalah sebagai berikut. 
[3] "Pendapat apa yang mendukung argumen Anda?"

Level IV - High Order Divergent; level ini membutuhkan siswa untuk berpikir evaluasi. Level pertanyaan ini bertujuan agar siswa membuat sebuah prediksi, memecahkan masalah dll. Level ini merepresentasikan bentuk tertinggi dari pola berpikir. Level IV ini sesuai dengan level "sintesis" dan "evaluasi" dalam taksonomi Bloom. Pada level ini siswa diharapkan dapat mengusulkan solusi, membuat hipotesis, memberi opini, menilai, dan memprediksi. Contoh pertanyaan pada level ini adalah sebagai berikut.

[4] "Dengan kejadian kebakaran hutan yang terjadi di Indonesia, apakah tindakan yang tepat untuk dilakukan?"

Penggunaan tuturan bertanya dalam konteks pembelajaran di kelas memiliki peranan yang penting baik dalam pengelolaan kelas maupun dalam rangka mencapai tujuan instruksional. Salah satu alasan seorang guru mengajukan pertanyaan kepada siswanya selama pembelajaran tidak untuk mendapatkan pengetahuan baru melainkan untuk menguji siswa sejauh mana siswa dapat memahami materi tersebut. Lebih spesifik lagi strategi bertanya dalam kelas digunakan untuk mendapatkan perhatian siswa, menguatkan gagasan, menguji pemahaman siswa, dan manajemen kelas (Wragg \& Brown, 2001: 7-9).

Wragg \& Brown menggolongkan menjadi tiga jenis pertanyaan dalam konteks pembelajaran yang didasarkan pada isi pertanyaan. Ketiga jenis pertanyaan tersebut, yaitu pertanyaan konseptual, pertanyaan empiris, dan pertanyaan nilai (Wragg \& Brown, 2001: 16-17). Berikut paparan ketiga jenis pertanyaan yang didasarkan pada isi pertanyaan.

Pertama, pertanyaan konseptual adalah pertanyaan yang menekankan pada pemerolehan ide, definisi dan alasan pada materi pelajaran yang dipelajari siswa. Contoh dalam pembelajaran pertanyaan jenis ini dapat diajukan oleh guru untuk meminta definisi konsep tertentu atau klasifikasi terkait konsep tertentu. Misalnya, pertanyaan berikut ini.
[5] "Apa saja yang termasuk ke dalam karya sastra?"

Pertanyaan tersebut menghendaki siswa untuk memberikan jawaban terkait konsep penggolongan jenis karya sastra. Jenis pertanyaan ini biasanya terkait dengan benar atau tidak jawaban siswa akan konsep tertentu.

Kedua, pertanyaan empiris adalah pertanyaan yang membutuhkan jawaban berdasarkan fakta, temuan eksperimen dan pengalaman siswa. Jenis pertanyaan ini menghendaki siswa untuk memberikan jawaban yang didasarkan fakta yang kemudian dikonfirmasikan pada konsep tertentu. Jenis pertanyaan ini menghendaki data pendukung atas jawaban siswa.

Ketiga, pertanyaan nilai adalah pertanyaan yang terkait dengan isu-isu moral, sosial dan isu lingkungan. Pertanyaan ini merupakan pertanyaan yang erat kaitannya dengan kehidupan. Jenis pertanyaan ini juga menuntut siswa untuk lebih berpikir kritis karena siswa diminta memberikan solusi atau evaluasi atas isu-isu tertenti, seperti itu sosial, lingkungan, politik, dan lain sebagainya

\section{METODE}

Jenis penelitian ini adalah jenis penelitian kualitatif. Penelitian ini dilakukan dalam rentang waktu bulan Februari sampai Maret 2016. Data penelitian ini adalah ujaran guru bahasa Indonesia selama mengajar di kelas. Subjek penelitian ini adalah guru mata pelajaran bahasa Indonesia yang berjumlah empat orang. Data dikumpulkan dengan menggunakan tiga teknik pengumpulan data, yaitu teknik rekam, wawancara, dan observasi. Juga digunakan instrumen untuk menjaring data dari proses pengumpulan data (Bogdan \& Biklen, 1982: 73-74; Arikunto, 2010: 99; Moleong, 2014: 174-175). Pada tahap analisis data digunakan metode padan. Metode padan adalah metode analisis yang digunakan untuk menganalisis data (bahasa) dengan hal-hal yang berada di luar bahasa (Sudaryanto, 1993).

\section{HASIL DAN PEMBAHASAN}

Hasil analisis mengenai aspek pengetahuan dalam tindak tutur bertanya guru bahasa Indonesia menunjukkan ada empat temuan, 
yaitu tuturan tanya dengan level I-Low Order Convergent, level II-High Order Convergent, level III-Low Order Divergent, dan level IVHigh Order Divergent. Tuturan tanya level I adalah tuturan tanya yang paling banyak muncul. Padahal aspek pengetahuan dalam tuturan tanya level tersebut merupakan tingkatan yang sederhana atau rendah, karena hanya mencakup aspek "pengetahuan" pada klasifikasi Bloom. Pada level ini dikehendaki siswa untuk dapat menguasai ingatan atau pengetahuan akan materi tertentu. Hasil analisis juga menunjukkan konten dari tuturan bertanya guru bahasa Indonesia dalam proses pembelajaran ditemukan ada tiga, yaitu pertanyaan konseptual, empiris dan pertanyaan nilai. Berikut paparan terkait aspek pengetahuan dan konten dalam tuturan bertanya guru bahasa Indonesia dalam proses pembelajaran.

\section{Aspek Pengetahuan dalam Tuturan Bertanya Guru Bahasa Indonesia}

Hasil analisis data diperoleh ada empat aspek pengetahuan dalam tindak tutur bertanya guru bahasa Indonesia. Aspek pengetahuan tersebut meliputi level I hingga level IV. Tuturan tanya dengan aspek pengetahuan level I yang paling banyak muncul dalam proses pembelajaran bahasa Indonesia. Adapun keempat level atau tingkatan tuturan bertanya guru bahasa Indonesia yang muncul dalam proses pembelajaran adalah sebagai berikut.

\section{Tuturan Bertanya Level I - Low Order Convergent}

Tuturan tanya dengan level I-Low Order Convergent ditemukan paling banyak muncul dalam kegiatan pembelajaran bahasa Indonesia. Tuturan tanya level I banyak dimanifestasikan dalam tuturan bertanya dengan menggunakan kata tanya. Pada tuturan tanya ini sebagaian besar memiliki fungsi asertif untuk menguji (Tabel. 1, p. 7). Di dalam proses pembelajaran, tuturan tanya ini banyak diajukan guru dengan meminta jawaban siswa terkait definisi dan menjawab benar atau salah dalam materi pelajaran tertentu. Berikut data tuturan bertanya dengan aspek pengetahuan level I-Low Order Convergent dalam kegiatan pembelajaran bahasa Indonesia di SMA Muhammadiyah Wonosobo.
[1] "Unsur yang membangun karya sastra ada berapa?" (05/GR/01)

Konteks: Guru mengapersepsi siswa dengan mengajukan pertanyaan terkait unsur pembangun karya sastra.

Tuturan [1] diujarkan guru pada kegiatan awal pembelajaran dengan tujuan untuk mengingatkan siswa akan materi pelajaran yang telah dipelajari pada beberapa waktu yang lalu. Tuturan tersebut dapat digolongkan ke dalam tuturan tanya dengan level I-Low Order Convergent, karena pertanyaan tersebut menghendaki siswa untuk menyebutkan unsur yang membangun karya sastra. Dalam hal ini pengetahuan siswa diuji dengan guru mengajukan pertanyaan, sehingga siswa melakukan proses pengingatan terkait materi unsur pembangun karya sastra. Hal yang sama juga terlihat dalam tuturan tanya berikut ini.

[2] "Nomina itu apa?" (25/GB/12)

Konteks: Guru menguji pengetahuan siswa terkait kategori kata.

[3] "Struktur teks negosiasi meliputi apa saja?" (07/GE/16)

Konteks: Guru menguji ingatan siswa terkait materi pelajaran yang telah lalu pada kegiatan awal pembelajaran.

Tuturan tanya [2] dan [3] dapat digolongkan ke dalam tuturan tanya level I-Low Order Convergent karena tuturan tanya tersebut hanya menghendaki jawaban pada tingkat pengetahuan. Pada tuturan tanya [2] siswa diuji pengetahuannya terkait pengertian atau definisi dari kategori kata, yaitu nomina. Pada tuturan tanya [3] siswa dikehendaki dapat mengidentifikasi struktur teks negosiasi. Kemampuan siswa untuk mengingat kembali terkait definisi dan mengenali struktur teks tersebut yang membuat tuturan tanya semacam itu digolongkan ke dalam tuturan tanya level I-Low Order Convergent.

Dari uraian tersebut dapat disimpulkan tuturan [1] sampai [3] merupakan tuturan tanya dengan aspek pengetahuan level I-Low Order Convergent. Hal tersebut dikarenakan tuturan tanya [1] sampai [3] menghendaki jawaban yang terkait definisi dan identifikasi terkait konsep tertentu. Jawaban dari pertanyaan tersebut me- 
musat, artinya mengacu pada konsep tertentu. Oleh karena itu, tuturan tanya semacam itu digolongkan ke dalam tuturan tanya level I karena hanya sampai pada tataran pengetahuan.

Pada ketiga tahapan pembelajaran, yaitu awal, inti, dan akhir, tuturan tanya dengan level Low Order Convergent paling banyak muncul. Di dalam kegiatan awal pembelajaran banyak tuturan tanya level I yang berkonten empiris. Hal tersebut dikarenakan pada kegiatan awal guru banyak mengajukan pertanyaan yang difungsikan untuk menegaskan terkait materi yang telah dipelajari. Tuturan tanya dengan aspek ini banyak muncul dalam kegiatan inti pembelajaran dan tuturan tanya level I banyak yang bersifat konseptual. Pada kegiatan inti pembelajaran, guru banyak mengajukan pertanyaan terkait definisi, identifikasi terkait konsep materi pelajaran tertentu. Hal tersebut dimungkinkan karena dalam kegiatan inti pembelajaran tujuan pembelajaran akan dicapai, sehingga siswa diminta untuk dapat menguasai konsep-konsep tertentu terkait materi pelajaran.

\section{Tuturan Bertanya Level II - High Order Convergent}

Dari hasil analisis ditemukan tuturan tanya dengan level II-High Order Convergent muncul sebanyak 115 tuturan. Tuturan tanya level II sebagaian besar berfungsi asertif, yaitu untuk menguji. Konten dari tuturan tanya ini lebih banyak bersifat konseptual (Tabel. 1, p. 7). Hal tersebut dikarenakan dalam tuturan tanya II siswa dikehendaki untuk dapat membandingkan, memberi contoh dan mengaplikasikan konsepkonsep materi pelajaran tertentu. Tuturan tanya dengan level ini paling banyak muncul pada kegiatan inti pembelajaran bahasa Indonesia. Adapun data tuturan dalam level II-High Order Convergent adalah sebagai berikut.

[4] "Konjungsi waktunya yang mana?" (06/ GE/14)

Konteks: Guru menguji pengetahuan siswa terkait ketepatan penggunaan konjungsi.

Tuturan tanya [4] dapat dimasukkan ke dalam tingkatan pertanyaan High Order Convergent karena tuturan tersebut menghendaki siswa untuk dapat membedakan penggunaan konjungsi secara tepat, dalam hal ini, yaitu contoh konjungsi temporal. Tuturan tanya tersebut meliputi aspek pengetahuan pemahaman dan aplikasi, sesuai dengan klasifikasi Bloom. Di dalam tuturan tanya tersebut, siswa diharapkan dapat membedakan penggunaan konjungsi dalam pengaplikasiannya dalam kalimat. Hal semacam itu juga dinyatakan oleh Kindsvatter, Willen, \& Ishler (1996), bahwa pada level atau tingkatan ini (High Order Convergent) siswa diharapkan dapat membandingkan, menginterpretasi, dan memberikan contoh, serta mengaplikasikan. Hal yang sama juga terlihat pada tuturan tanya berikut ini.

[5] "Sebenarnya yang menunjukkan subjeknya melakukan perbuatan atau tidak itu apanya?" (29/GB/02)

Konteks: Guru menguji pemahaman siswa terkait ciri-ciri fungsi dan kategori kata.

Pada tuturan tanya [5] siswa dikehendaki dapat memahami dan membedakan setiap fungsi kata dalam kalimat. Hal tersebut yang membuat tuturan tanya semacam itu dapat digolongkan ke dalam tuturan tanya level II-High Order Convergent. Tuturan tanya level merupakan tuturan tanya yang mencakup aspek pemahaman dan aplikasi sesuai dengan taksonomi Bloom. Tuturan tanya yang masuk ke dalam level II dapat diindikasikan dengan siswa dikehendaki dapat menginterpretasi, membedakan, memberikan contoh, dan mengaplikasikan dari sebuah teori tertentu.

Dari uraian tersebut dapat disimpulkan bahwa tuturan dengan level II-High Order Convergent adalah tuturan yang menghendaki atau menekankan siswa pada kemampuan untuk membandingkan, menginterpretasi, dan memberi contoh terkait konsep atau materi tertentu. Tuturan tanya dengan level ini paling banyak muncul pada kegiatan inti pembelajaran. Hal tersebut dimungkinkan, dalam kegiatan inti pembelajaran guru ingin mengetahui tingkat pemahaman materi hingga pengaplikasian materi yang telah dipelajari. Oleh karena itu, tuturan tanya level II banyak bersifat konseptual dan berfungsi asertif (menguji). 
Tuturan Bertanya Level III - Low Order Divergent

Hasil analisis menunjukkan tuturan tanya dengan level ini dalam kegiatan pembelajaran bahasa Indonesia hanya muncul sebanyak 23 tuturan tanya. Pada kegiatan awal pembelajaran tuturan level III muncul sebanyak 3 tuturan, kegiatan inti 17 tuturan, dan kegiatan akhir sebanyak 7 tuturan (Tabel. 1, p. 7). Adapun data tuturan tanya level III-Low Order Divergent yang muncul dalam pembelajaran bahasa Indonesia adalah sebagai berikut.

[6] "Tapi kalimatnya sudah betul atau belum?" (07/GE/14)

Konteks: Guru meminta siswa menganalisis kalimat yang menggunakan konjungsi.

[7] "Kenapa terjadi gerhana?" (04/GB/13)

Konteks: Guru melakukan apersepsi dengan bertanya jawab terkait peristiwa gerhana yang terjadi beberapa waktu yang lalu.

[8] "Berarti ada berapa unsur yang harus dilesapkan?" (39/GR/18)

Konteks: Guru meminta siswa untuk menganalisis kalimat majemuk.

Tuturan tanya [6] hingga [8] merupakan tuturan tanya yang dapat dimasukkan ke dalam tuturan tanya dengan level III-Low Order Divergent. Pada tuturan [6] siswa dikehendaki untuk dapat menganalisis kalimat dengan penggunaan konjungsi yang benar. Pemberian jawaban yang didasarkan pada analisis juga terlihat pada tuturan [7] dan [8]. Tuturan [7] menekankan agar siswa dapat memberikan alasan mengapa bisa terjadi gerhana. Dalam memberi penjelasan tentunya siswa telah mengetahui apa itu gerhana dan bagaimana dapat terjadi dengan penjelasan yang didukung oleh teori terkait. Pada tuturan tanya [8] siswa dikehendaki dapat membedakan antara kalimat tunggal dan majemuk. Siswa yang telah memahami konsep terkait kalimat tunggal dan majemuk akan dapat menjawab dengan didasarkan pada ciri-ciri kalimat, baik tunggal maupun majemuk. Oleh karena itu, data tuturan tanya yang menghendaki jawaban berupa jawaban analitis dapat dimasukkan atau digolongkan ke dalam tuturan tanya dengan level III-Low Order Divergent. Sesuai dengan yang diungkapkan oleh Kindvatter, Willen, \& Ishler, yaitu tuturan tanya pada level III mengharapkan jawaban terbuka dari siswa dan tuturan pada level ini menekankan siswa agar mampu menganalisis informasi, memberi bukti pendukung, menarik kesimpulan dan lain sebagainya. (Bloom, 1956; Kindsvatter, Willen, \& Ishler, 1996).

\section{Tuturan Bertanya Level IV - High Order Divergent}

Hasil analisis menunjukkan tuturan tanya dengan level IV hanya beberapa kali muncul dalam kegiatan pembelajaran. Sedikit sekali pertanyaan yang diajukan guru kepada siswa dengan level tinggi dan menghendaki siswa berpikir kompleks. Tuturan dengan level IV-High Order Divergent menghendaki siswa untuk dapat memberikan pendapat dan penilaian terhadap sesuatu. Tuturan tanya dengan level IV dapat dipastikan tuturan tersebut memiliki konten nilai (Tabel. 1, p. 7). Artinya, tuturan tanya tersebut menghendaki jawaban yang berupa pemberian penilaian atau evaluasi terkait isu-isu tertentu. Adapun data tuturan tanya dengan tingkatan ini adalah sebagai berikut.

[9] "Kemudian apa kelebihan dan kekurangn pada film?" (14/GR/07)

Konteks: Guru meminta siswa untuk mengevaluasi film.

[10] "Apa kekurangan dan kelebihan film tersebut?” (15/GR/07)

Konteks: Guru meminta siswa untuk membuat penilaian terhadap film.

Tuturan tanya [9] dan [10] merupakan tuturan tanya dengan level High Order Divergent. Pada kedua tuturan tanya tersebut, siswa dikehendaki membuat penilaian dan mengevaluasi film. Tuturan tanya level ini menghendaki jawaban terbuka dari siswa. Artinya, siswa diminta menilai sesuai dengan pikiran dan pendapat siswa itu sendiri disertai argumen yang mendukung. Tuturan tanya yang menghendaki siswa membuat penilaian sangat bagus untuk mengembangkan pola berpikir siswa. Tuturan tanya tersebut dapat menstimulasi dan mengeksplorasi pikiran siswa, sehingga daya kritis yang 
siswa punya terasah. Hal yang sama juga terlihat pada tuturan tanya berikut ini.

\section{[11] “Kenapa?" (04/GB/02)}

Konteks: Guru menanyakan alasan terkait judul resensi tidak harus sama dengan judul buku.

Tuturan [11] merupakan wujud penggunaan tuturan tanya dengan aspek pengetahuan yang tinggi, yaitu level IV (C5 dan C6). Hal tersebut dikarenakan tuturan tanya [11] menghendaki siswa untuk memberikan pendapatnya. Tuturan tanya tersebut menghendaki siswa menjawab dengan jawaban terbuka, yang berarti siswa dapat mengemukakan pendapatnya sendiri. Oleh karena itu, tuturan tanya tersebut dapat digolongkan ke dalam tuturan tanya level IV. Tuturan tanya dengan level IV merupakan tuturan tanya dengan tingkat kompleksitas yang tinggi. Seperti yang dinyatakan oleh Kindsvatter, Willen, \& Ishler (1996), tuturan tanya level IV memuat pertanyaan yang dapat membuat siswa untuk mengusulkan/memberikan solusi, memecahkan masalah, menilai dan lain-lain.

Data hasil analisis menunjukkan bahwa tuturan tanya level IV-High Order Divergent tidak terlalu banyak muncul dalam proses pembelajaran bahasa Indonesia. Tuturan tanya tersebut muncul dalam kegiatan awal dan akhir pembelajaran, namun paling banyak muncul pada kegiatan awal pembelajaran. Padahal tuturan tanya level ini merupakan tuturan tanya dengan tingkatan yang kompleks dan dapat melatih siswa berpikir kritis. Sesuai dengan pernyataan Bloom (1956), pada tingkatan evaluasi siswa dituntut untuk dapat memberikan penilaian terhadap sesuatu. Oleh karena itu, pengajuan pertanyaan dengan tingat kompleks dapat membantu mengembangkan pola pikir siswa ke arah yang lebih tinggi. Hasil analisis terkait aspek pengetahuan dalam tuturan bertanya guru bahasa Indonesia tercantum dalam tabel berikut ini.

Tabel 1. Aspek Pengetahuan dalam Tuturan Bertanya Guru Bahasa Indonesia

\begin{tabular}{|c|c|c|c|c|c|c|c|c|}
\hline & \multicolumn{4}{|c|}{ Aspek Pengetahuan } & \multicolumn{3}{|c|}{ Isi } \\
\hline & & I & II & III & IV & $\mathrm{Kn}$ & Em & $\mathrm{Nl}$ \\
\hline \multicolumn{9}{|c|}{ Kegiatan Awal Pembelajaran } \\
\hline \multirow{4}{*}{$\begin{array}{l}\frac{y}{\Delta} \\
\frac{2}{2} \\
\frac{n}{4}\end{array}$} & I & 183 & & & & 72 & 110 & 1 \\
\hline & II & & 14 & & & 12 & 2 & \\
\hline & III & & & 3 & & & 3 & \\
\hline & IV & & & & 8 & 2 & & 6 \\
\hline \multicolumn{9}{|c|}{ Kegiatan Inti Pembelajaran } \\
\hline \multirow{4}{*}{$\begin{array}{l}\frac{x}{0} \\
\frac{0}{2} \\
\frac{0}{4}\end{array}$} & $\mathrm{I}$ & 186 & & & & 100 & 86 & \\
\hline & II & & 97 & & & 92 & 5 & \\
\hline & III & & & 13 & & & 13 & \\
\hline & IV & & & & & & & \\
\hline \multicolumn{9}{|c|}{ Kegiatan Akhir Pembelajaran } \\
\hline \multirow{4}{*}{$\begin{array}{l}\frac{y}{0} \\
\frac{2}{2} \\
\frac{0}{4}\end{array}$} & I & 16 & & & & 3 & 13 & \\
\hline & II & & 4 & & & 4 & & \\
\hline & III & & & 7 & & & 7 & \\
\hline & IV & & & & 4 & & & 4 \\
\hline \multicolumn{9}{|c|}{ Keterangan } \\
\hline $\mathrm{Y} / \mathrm{t}=$ & $=$ Ya/tidak & As & $=$ Asertif & I & $=$ Level I & $\mathrm{Kn}$ & $=$ Konseptual & \\
\hline $\mathrm{Eb}=$ & $=$ Embelan & $\mathrm{Dr}$ & $=$ Direktif & II & $=$ Level II & $\mathrm{Em}$ & $=$ Empiris & \\
\hline Alt $=$ & $=$ Alternatif & $\mathrm{Km}$ & $=$ Komisif & III & $=$ Level III & $\mathrm{Nl}$ & $=$ Nilai & \\
\hline $\mathrm{Rt}=$ & $=$ Retoris & $\mathrm{Ek}$ & $=$ Ekspresif & IV & $=$ Level IV & & & \\
\hline $\mathrm{KT}=$ & $=$ Kata Tanya & $\mathrm{Dk}$ & $=$ Deklaratif & & & & & \\
\hline
\end{tabular}


Dari tabel 1 tersebut dapat disimpulkan beberapa hal sebagai berikut. Pertama, tuturan tanya dengan level I-Low Order Convergent merupakan tuturan tanya yang paling banyak muncul dalam kegiatan pembelajaran, baik pada kegiatan awal, inti maupun akhir pembelajaran. Pada tuturan tanya level I banyak ditanyakan hal-hal yang berkaitan dengan konsep, seperti definisi dan identifikasi. Kedua, tuturan tanya level II-High Order Convergent kemunculannya paling banyak pada kegiatan inti pembelajaran. Tuturan tanya level II menghendaki siswa dapat menginterpretasi, memberikan contoh, dan mengaplikasikan konsep-konsep terkait materi yang telah dipelajari. Ketiga, tuturan tanya level III-Low Order Divergent tidak begitu banyak kemunculannya dalam kegiatan pembelajaran. Tuturan tanya level III ini banyak yang berkonten empiris. Hal tersebut dikarenakan, dalam tuturan tanya level III, siswa banyak diminta untuk menganalisis. Kegiatan analisis tersebut termasuk dalam kegiatan siswa menemukan jawaban yang didasarkan hasil temuan, sehingga tuturan tanya level III berkaitan dengan tuturan tanya berkonten empiris. Keempat, tuturan tanya level IV merupakan tuturan tanya yang sedikit muncul dalam kegiatan pembelajaran bahasa Indonesia. Tuturan tanya level IV berkaitan dengan tuturan tanya berkonten nilai. Hal tersebut dikarenakan dalam tuturan tanya level IV siswa diminta memberikan penilaian terkait isu-isu tertentu, yang dikehendaki juga dalam pertanyaan-pertanyaan nilai.

\section{Konten Tuturan Bertanya Guru Bahasa Indonesia}

Hasil analisis terkait isi tindak tutur bertanya guru bahasa Indonesia selama porses pembelajaran diperoleh tiga hasil temuan, yaitu tuturan bertanya konseptual, tuturan bertanya empiris, dan tuturan bertanya nilai. Dalam penelitian ini juga dipaparkan isi tuturan tanya dalam ketiga tahapan pembelajaran, yaitu kegiatan awal, inti, dan akhir. Hal tersebut dilakukan untuk mengetahui karakteristik isi tuturan tanya yang muncul pada setiap tahapan pembelajaran. Berikut paparan ketiga isi tuturan bertanya dalam pembelajaran bahasa Indonesia.

\section{Tuturan Bertanya Konseptual}

Berdasarkan hasil analisis isi tuturan bertanya guru bahasa Indonesia diperoleh hasil, yaitu tuturan bertanya konseptual yang sering muncul selama proses pembelajaran, khususnya pada kegiatan inti pembelajaran (Tabel. 2, p. 10). Tuturan bertanya konseptual dapat dipastikan memiliki fungsi asertif untuk menguji atau pun menegaskan. Hal tersebut dikarenakan di dalam tuturan bertanya konseptual siswa dikehendaki dapat mengingat dan memahami terkait konsep-konsep materi pelajaran tertentu. Tuturan bertanya konseptual ini banyak muncul dalam kegiatan inti pembelajaran. Hal ini dimungkinkan kegiatan inti pembelajaran merupakan tahapan pembelajaran untuk mencapai tujuan pembelajaran. Oleh karena itu, pada kegiatan tersebut guru banyak mengajukan pertanyaan terkait konsep-konsep materi tertentu sesuai dengan tujuan pelajaran yang akan dicapai. Berikut ini adalah beberapa data-data tuturan bertanya guru bahasa Indonesia yang memiliki isi konseptual pada proses pembelajaran bahasa Indonesia.

[12] "Unsur ekstrinsik itu apa?" (04/GR/07)

Konteks: Guru menanyakan pengertian dan halhal yang termasuk ke dalam unsur ekstrinsik dalam karya sastra.

[13] "Apa itu negosiasi?" (05/GT/09)

Konteks: Guru meminta siswa untuk mendeskripsikan istilah negosiasi.

Seperti pada data tuturan [12] "Unsur ekstrinsik itu apa?". Tuturan tersebut digolongkan ke dalam pertanyaan konseptual karena menekankan pada siswa untuk mengingat kembali definisi unsur ekstrinsik. Sama seperti pada data tuturan [13] “Apa itu negosiasi?". Tuturan tersebut juga menanyakan terkait definisi. Tuturan tanya [12] dan [13] dituturkan guru dengan maksud supaya siswa benar-benar mengetahui dan paham terkait konsep unsur pembenagun karya sastra dan definisi negosiasi. Sebuah pertanyaan yang diajukan dan meminta penjelasan terkait definisi termasuk ke dalam pertanyaan konseptual. Jenis pertanyaan ini disebut dengan pertanyaan konseptual (Wragg \& Brown, 2001). Hal yang sama juga terlihat dalam tuturan tanya berikut ini. 
[14] "Yang sangat membedakan drama dengan yang lain itu apa?(24/GR/01)

Konteks: Guru menguji pengetahuan siswa terkait perbedaan drama dengan genre sastra yang lain.

[15] "Ide pokok paragraf di awal namanya deduktif apa induktif?"(14/GE/03)

Konteks: Guru menguji pengetahuan siswa terkait jenis paragraf berdasarkan letak kalimat utamanya.

Data tuturan tanya [14] dan [15] dapat digolongkan ke dalam tuturan tanya konseptual. Hal tersebut dikarenakan pada tuturan tanya [14] dan [15] menghendaki siswa untuk menjawab terkait konsep-konsep materi tertentu. Pada tuturan [14] guru ingin mengetahui pemahaman siswa terkait karakteristik beberapa genre sastra, dalam hal ini, yaitu membedakan drama dengan genre sastra yang lain. Dalam menjawab pertanyaan tersebut siswa dituntut dapat mengetahui dengan pasti pengertian dan karakteristik setiap genre sastra, sehingga siswa dapat membedakan genre yang satu dengan yang lain. Sama halnya dengan tuturan tanya [15]. Tuturan tersebut juga menghendaki siswa menjawab pertanyaan yang didasarkan pada konsep tertentu, yaitu memahami konsep terkait jenis paragraf yang didasarkan pada letak kalimat utamanya. Oleh karena itu, tuturan tanya tersebut dapat digolongkan ke dalam tuturan tanya konseptual.

Berdasarkan hasil analisis, dapat disimpulkan bahwa pertanyaan konseptual lebih banyak muncul pada kegiatan inti pembelajaran. Tuturan tanya tersebut diajukan guru dengan maksud agar siswa paham dengan konsepkonsep terkait materi tertentu yang dipelajari. Hal tersebut juga dikuatkan dengan wawancara terhadap guru bahasa Indonesia yang menyatakan bahwa, siswa diharapkan dapat menguasai konsep-konsep tertentu terkait materi pelajaran, dalam hal ini, meliputi jenis, struktur, fungsi berbagai jenis teks, sehingga siswa dapat mengaplikasikan dengan memproduksi teks setelah tahu dan paham akan konsep-konsep materi tertentu.

\section{Tuturan Bertanya Empiris}

Hasil temuan menunjukkan pertanyaan empiris banyak muncul dalam kegiatan awal pembelajaran bahasa Indonesia, yaitu pada kegiatan apersepsi. Hasil analisis menunjukkan tuturan tanya empiris sebagaian besar berfungsi asertif, yaitu menegaskan, dan tuturan ini diwujudkan dalam bentuk tuturan Ya/tidak (Tabel. 2, p. 10). Hal tersebut dilakukan oleh guru guna memberi pengetahuan dasar kepada siswa. Seperti yang telah dikemukakan Akbar, bahwa tujuan guru memberi apersepsi adalah untuk memberi landasan dasar kepada siswa sebelum siswa mendapat pengetahuan baru (Akbar, 2013). Berikut beberapa data tuturan tanya empiris dalam pembelajaran bahasa Indonesia. [16] "Paham ya?" (17/GT/04)

Konteks: Guru menegaskan siswa bahwa telah memahami materi yang diajarkan.

[17] "Jadi, kalian sudah bisa mengidentifikasi, sudah atau belum?"(30/GE/16)

Konteks: Guru mengonfirmasi bahwa siswa telah dapat mengaplikasikan konsep yang telah dipelajari.

[18] "Misalnya, “Adik makan bakso.”, kalimat tunggal atau kalimat majemuk?" (19/ $\mathrm{GB} / 11$ )

Konteks: Siswa diminta untuk menganalisis terkait kalimat tunggal dan majemuk.

Data tuturan tanya [16] hingga [18] merupakan data tuturan yang empiris, karena jawaban yang dikehendaki didasarkan pada pengalaman dan hasil temuan siswa. Tuturan [16] "Paham ya?". Tuturan tersebut diujarkan guru untuk menegaskan kepada siswa apakah sudah paham materi yang diajarkan pada waktu itu. Guru ingin mengetahui sejauh mana pemahaman siswa akan materi yang diajarkan selama siswa mengikuti pelajaran pada hari itu. Tuturan tanya tersebut menghendaki jawaban berdasarkan pengalam siswa selama mengikuti pelajaran. Tuturan [17] juga menghendaki jawaban berdasarkan pengalaman siswa selama mengikuti pelajaran. Pada tuturan [18] terlihat siswa diminta untuk menganalisis sebuah kalimat, yaitu membedakan kalimat tunggal dan 
majemuk. Artinya, jika siswa dapat menjawab pertanyaan tersebut dengan menganalisisnya, maka siswa tersebut telah dapat menjawab pertanyaan berdasarkan hasil temuan. Hal ini berarti jenis tuturan tanya yang seperti itu dapat digolongkan ke dalam jenis tuturan tanya empiris. Hal yang sama juga terlihat pada tuturan tanya berikut ini.

[19] "Kemudian Anda mengamati gerhana nggak?" $(02 / \mathrm{GB} / 13)$

Konteks: Guru melakukan kegiatan apersepsi dengan bertanya jawab seputar peristiwa gerhana yang terjadi pada hari sebelumnya.

[20] "Siapa yang pernah menyaksikan drama secara langsung?" (23/GR/10)

Konteks: Guru menegaskan apakah siswa pernah menonton drama secara langsung.

[21] "Kalian pernah melihat film Tenggelamnya Kapal Van Der Wijck?” (31/GE/14)

Konteks: Guru menegaskan siswa telah menonton film yang dimaksud.

Data-data tuturan tanya empiris yang berkaitan dengan pengalaman siswa di luar materi pelajaran terlihat pada data tuturan [19], [20], dan [21]. Data tuturan tanya tersebut menghendaki jawaban siswa berdasarkan pengalaman di luar materi pelajaran. Seperti pengalaman siswa terkait fenomena alam, pengalaman menonton film atau drama. Seperti pada tuturan [19] "Kemudian Anda mengamati gerhana nggak?". Tuturan tanya tersebut diajukan guru setelah ada fenomena gerhana matahari pada hari sebelumnya. Guru mengajukan pertanyaan tersebut menghendaki jawaban yang didasarkan pada pengalaman siswa melihat gerhana matahari. Seperti juga yang terlihat pada data tuturan [20] dan [21]. Tuturan tersebut menghendaki jawaban siswa berdasarkan pada pengalaman siswa menonton drama secara langsung dan film yang dimaksudkan.

Dari uraian tersebut dapat disimpulkan bahwa tuturan tanya empiris menghendaki jawaban yang didasarkan pada fakta, hasil temuan eksperimen, dan pengalaman siswa. Tuturan tanya empiris lebih banyak muncul pada kegiatan awal pembelajaran. Hal tersebut cukup beralasan karena pada kegiatan awal pembela- jaran guru memberi dasar pengetahuan kepada siswa sebelum masuk pada materi yang baru, baik yang terkait pelajaran yang lalu maupun bertanya jawab mengenai isu-isu di seputar kehidupan. Kegiatan tersebut juga dimaksudkan untuk membentuk kondisi psikologis siswa agar siswa siap dalam mengikuti pelajaran dan menerima materi yang baru pada hari itu.

\section{Tuturan Bertanya Nilai}

Hasil analisis menunjukkan tuturan tanya nilai jarang muncul pada proses pembelajaran bahasa Indonesia. Tuturan bertanya nilai berkaitan dengan aspek pengetahuan yang kompleks, yaitu level IV (Tabel. 2, p. 10). Hal tersebut dikarenakan dalam tuturan nilai siswa dikehendaki menjawab pertanyaan yang terkait isu-isu tertentu (sosial, agama, pendidikan, ekonomi, dll). Dalam menjawab, siswa dituntut memberi jawaban yang analitis yang juga didukung dengan pendapat dan diminta memberi penilaian atau evaluasi terkait isu tertentu. Jenis pertanyaan ini hanya beberapa kali muncul dalam proses pembelajaran bahasa Indonesia. Adapun data tuturan tanya nilai yang terdapat dalam proses pembelajaran bahasa Indonesia adalah sebagai berikut.

[22] "Boleh tidak itu dalam islam?" (15/GB/13) Konteks: Guru meminta pendapat siswa terkait fenomena yang terjadi beberapa waktu yang lalu, yaitu fenomena LGBT.

[23] "Nah sekarang, tadi ingat Tenggelamnya Kapal Van der Wicjk, coba menurut kalian evaluasinya bagaimana?" (29/GE/06)

Konteks: Guru meminta siswa untuk melakukan penelaian (kelebihan dan kekurangan) film yang pernah ditonton.

Data tuturan tanya [22] termasuk data tuturan tanya nilai karena tuturan tersebut terkait isu yang sedang terjadi, yaitu LGBT. Siswa diminta pendapatnya dan penilaiannya terkait peristiwa tersebut dari pandangan agama islam. Hal yang sama juga terlihat pada data tuturan tanya [23]. Tuturan tanya [23] termasuk ke dalam tuturan tanya (pertanyaan) nilai karena tuturan tanya tersebut menghendaki jawaban dari siswa terkait isu tertentu, yaitu apresiasi karya 
sastra. Dalam hal ini siswa diminta pendapatnya untuk mengevaluasi film Tenggelamnya Kapal Van Der Wijck. Oleh karena itu, data tuturan tersebut dapat dikelompokkan ke dalam tuturan tanya (pertanyaan) nilai karena menghendaki jawaban yang terkait isu-isu tertentu.

Berdasarkan tabel 2 tersebut dapat disimpulkan. Pertama, pertanyaan konseptual banyak muncul dalam kegiatan inti pembelajaran. Hal tersebut dikarenakan, pada kegiatan inti pembelajaran tujuan pembelajaran akan dicapai, sehingga pada kegiatan tersebut guru lebih banyak mengajukan pertanyaan yang bersifat konseptual. Kedua, tuturan tanya empiris banyak muncul pada kegiatan awal pembelajaran. Tuturan tanya empiris juga lebih banyak diwujudkan dalam jenis tuturan tanya Ya/tidak. Ketiga, tuturan tanya nilai tidak banyak muncul dalam pembelajaran. Tuturan tanya ini berkaitan dengan aspek pengetahuan tingkat tinggi, karena tuturan tanya ini mengharapkan siswa menjawab dengan jawaban yang kritis dan memberikan evaluasi.

\section{SIMPULAN}

Hasil analisis terkait aspek pengetahuan dalam tindak tutur bertanya guru bahasa Indone- sia dalam kegiatan pembelajaran ditemukan ada empat tingkatan aspek pengetahuan. Keempat tingkatan tersebut, yaitu level I-Low Order Convergent, level II-High Order Convergent, level III-Low Order Divergent, level IV-High Order Divergent. Dari keempat tingkatan/ level tuturan bertanya guru bahasa Indonesia, tuturan tanya dengan aspek pengetahuan level I-Low Order Convergent yang paling banyak muncul. Tuturan bertanya dengan level tersebut merupakan tuturan tanya yang paling sederhana karena di dalam pertanyaan hanya mencakup aspek "pengetahuan". Aspek "pengetahuan" ini hanya menekankan siswa untuk mampu mendefinisi, mengidentifiksasi, menjawab benar atau salah, dan lain-lain. Hasil temuan ini juga mengukuhkan penelitian yang dilakukan oleh Syamsi dengan hasil temuan strategi bertanya guru dalam pembelajaran banyak menggunakan strategi konvergen (82\%). Strategi tersebut masuk ke dalam kemampuan berpikir tingkat sederhana/rendah.

Hasil analisis menunjukkan tuturan bertanya yang didasarkan pada isi ditemukakn ada tiga temuan, yaitu pertanyaan konseptual, empiris, dan nilai. Pada kegiatan awal pembelajaran banyak ditemukan tuturan tanya empiris.

Tabel 2. Konten Tuturan Bertanya Guru Bahasa Indonesia

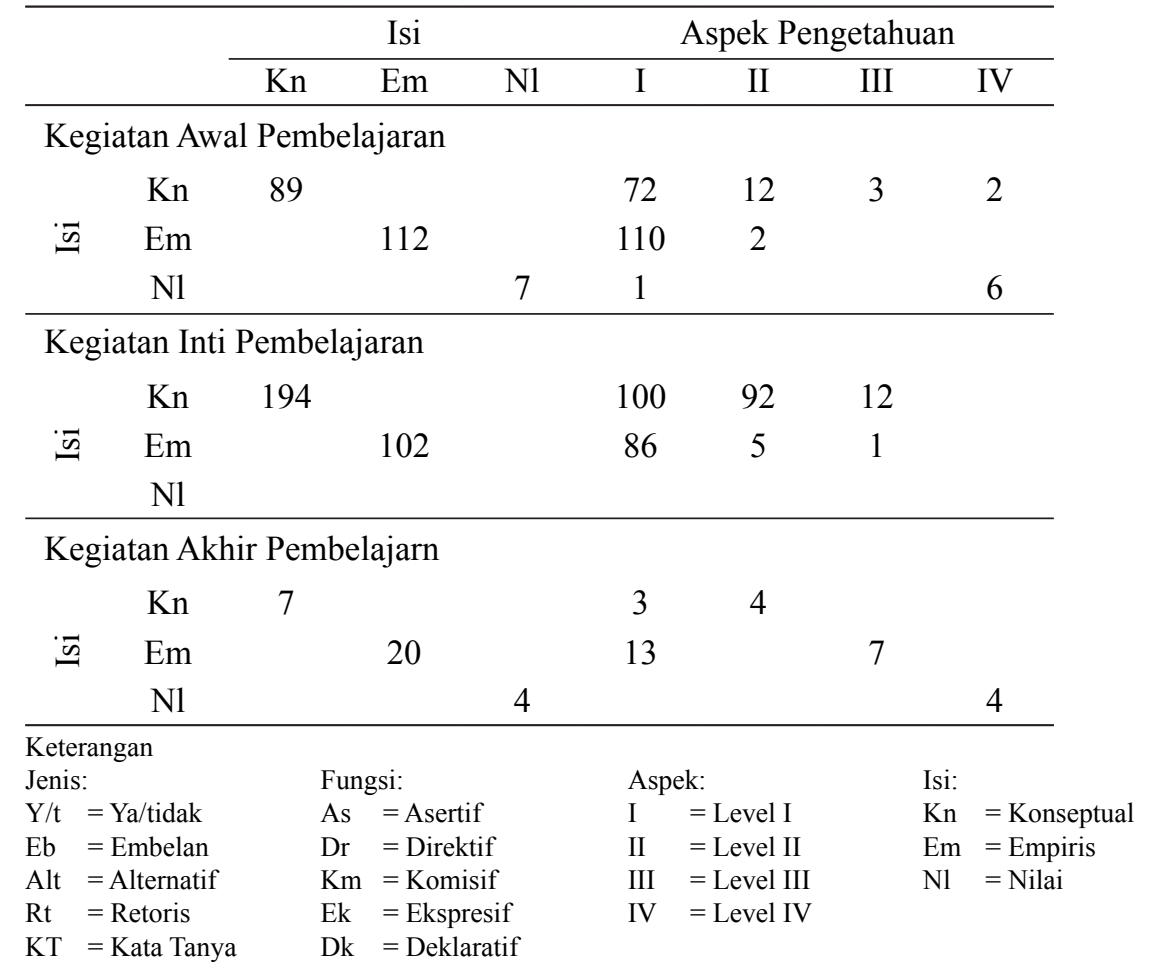

Aspek Pengetahuan dalam Tuturan Bertanya Guru Bahasa Indonesia ... (Guntur Sakti Dewangga) 
Hal tersebut dikarenakan pada kegiatan awal pembelajaran guru mengajukan beberapa pertanyaan, baik yang berkaitan dengan pengalaman siswa terkait materi pelajaran maupun di luar materi pelajaran, untuk memberi landasan pengetahuan bagi siswa. Pada kegiatan inti pembelajaran, guru banyak mengajukan pertanyaan konseptual. hal tersebut dimungkinkan pada kegiatan tersebut tujuan pembelajaran akan dicapai, sehingga guru lebih menekankan pada konsep-konsep terkait materi yang dipelajari.

\section{DAFTAR PUSTAKA}

Arikunto, S. 2010. Prosedur Penelitian: Suatu Pendekatan Praktik. Jakarta: Rineka Cipta.

Bloom, B. S. 1956. Taxonomy of Educational Objective. London: Longmans.
Bogdan, R. C., \& Biklen, S. K. 1982. Qualitative Research for Education: an Introduction to Theory and Methods. Boston: Allyn and bacon.

Kindsvatter, R., Wilen, W., \& Ishler, M. 1996. Dynamics of Effective Teaching (3 ${ }^{\text {rd }}$ ed.). USA: Longman.

Moleong, L.J. 2014. Metodologi Penelitian Kualitatif (Rev. ed.). Bandung: Remaja Rosdakarya.

Sudaryanto. 1993. Metode dan Aneka Analisis Bahasa. Yogyakarta: Duta Wacana University Press.

Syamsi, K. 2015. Strategi Bertanya dalam Pembelajaran Bahasa Indonesia di SMP. Universitas Negeri Yogyakarta.

Wragg, E. C., \& Brown, G. (2001). Questioning in the Secondary School. London: Routledge. 